\title{
SPATIAL CONCENTRATION OF INDUSTRY AND LOCAL PRODUCTION SYSTEMS IN UKRAINE ${ }^{1}$
}

\begin{abstract}
The paper is dedicated to the analyses of preconditions for the creation and development of local production systems (LPS) at the territory of Ukraine as recognized by international law. Theoretical part of the research highlights LPS as a specific type of economic agglomeration and represents the comparison between traditional agglomerative forms (metropolises and industrial districts) and more innovative alliances (LPS and creative regions). The peculiarities, advantages and participants of LPS are considered also in the theoretical part.

Analytical part of the research determines spatial concentration of industry based on traditional industrial districts. Also specific legal regimes for the regions of Ukraine such as special (free) economic zones, priority development areas, technology and science parks are considered preconditions for LPS development. Finally, currently operating LPS in Ukraine and recommendations for their development are presented.
\end{abstract}

Keywords: local production system, cluster, agglomeration, industrial district, special economic zone, preferential development area.

\section{INTRODUCTION}

Modern development of the world economy is determined by dialectical unity of two trends contradictory at first sight: globalization and concentration (the so called "global paradox" - see J. Naisbitt, D. Lukyanenko). Globalization of production means location next to the final consumer is no longer necessary, as with the development of telecommunications and transport infrastructure, geographical distance is not a barrier for international economic relations (economy of globality). But, on the other hand, under the current conditions competitive advantages occur mainly at the local level - more information about the structure of consumer market, the availability of business contacts, better reputation and instant response to the changes of demand - that is what distant rivals cannot achieve. So the opposite phenomenon is the economy of proximity.

* Ternopil National Economic University, Department of International Economics.

${ }^{1}$ This article was prepared as part of the $7^{\text {th }}$ Framework Programme FP7-PEOPLE-2011-IRSES Project No. 295050 FOLPSEC - Functioning of the local production systems in the conditions of economic crisis (comparative analysis and benchmarking for the EU and beyond). 
Indissoluble unity of internationalization and regionalization ("glocalization") likewise integration and fragmentation ("fragmegration") create the architecture of the global economy, causing gravity processes, which form agglomerative alliances of both producers and consumers. Under the influence of the centripetal and centrifugal forces, stable "cores" emerge, while other areas remain "peripheries" and are forced to be "transit deserts".

The paper aims to analyze how regions of Ukraine are involved in the processes of spatial industrial concentration, as well as to determine the preconditions for the creation and development of innovative LPS-alliances at their territories.

\section{ECONOMIC ESSENCE OF LOCAL PRODUCTION SYSTEM}

Local production systems (LPS) are structures, which combine the best features of agglomeration economies acting globally. Before defining the LPS, it should be noted that the agglomeration, regardless of its type, combines urbanization (location close to the other manufacturers of the widely diversified goods and services) and localization (close to other producers of similar goods and services) (Sölvell 2009: 140). Thus, traditional forms of agglomeration are cities and industrial districts. In Ukrainian economic literature the agglomeration is also considered mainly in two separate aspects (Mochernyi 2002):

1. Metropolitan areas - compact spatial location of urban settlements, joined with the intensive economic, cultural and social ties;

2. Industrial agglomeration - spatial concentration of industry and diversified industrial centers on a relatively small area. Like the previous form, industrial agglomeration can concentrate around a single industrial object (especially typical for monoindustrial cities of the former Soviet Union and the Scandinavian "bruks") or to consists from a number of the interrelated equal objects.

The first type of agglomeration is associated with general benefits of territorial concentration, in particular lower transport costs and economies of scale in production. I Interaction of gravity forces leads to the formation of metropolitan areas, which have a wide range of economic activities.

The emergence of agglomeration advantages of the second type due to the proximity of firms engaged into similar or interconnected activities leads to the emergence of the industrial districts. Similarly to the case of the metropolis, close ties between firms and institutions within a given geographical area are based on the exploitation of the economies of scale and of scope, accumulation of specialized skills, common infrastructure, and other externalities. 
However, it should be noted that the above mentioned traditional forms of agglomeration gradually lose their comparative advantage. Being rather "clumsy" structures, they are not always able to respond to rapid changes in the global environment, especially in the light of the recent crisis. Unfavorable situation in the energy market has led to the suspension of a huge number of industrial facilities, which pushed population of many monoindustrial mining or steel cities below the poverty line.

Therefore, during the last decades along with the traditional forms, we can observe new alliances with a clear innovation focus. Such knowledge generating centers may have various structures. In this paper, despite their considerable diversity, we call them LPS or clusters. LPS are usually based on the principle of close specialization. Another type of agglomerative structure - a creative region - also has an innovative focus, but is founded on diverse activities (Figure 1).

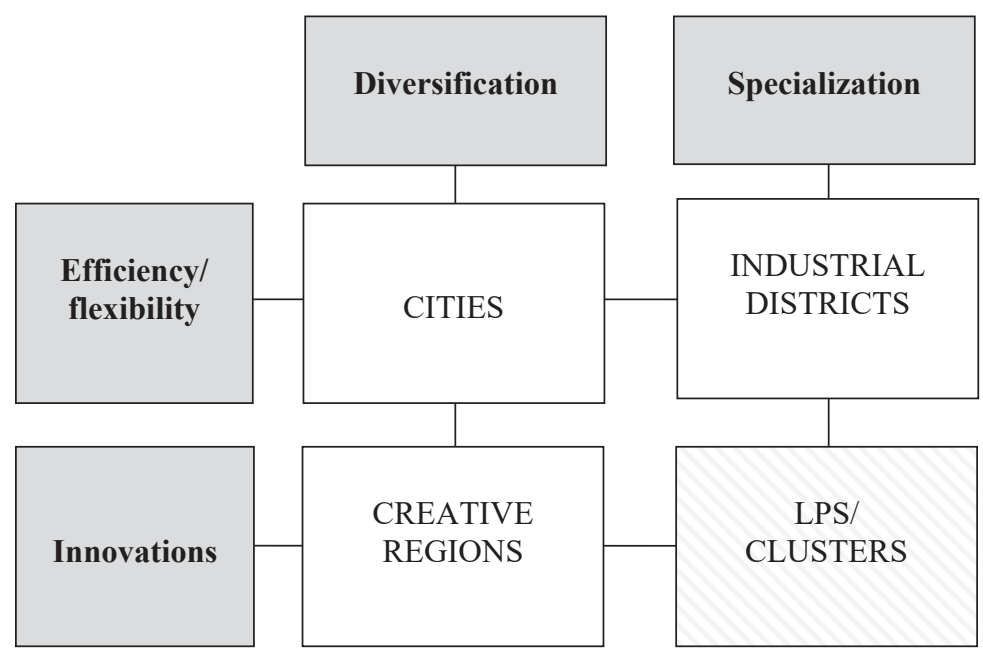

Figure 1. Forms of agglomeration

Source: author's modification of (Sölvell 2009: 140).

So, LPS are territorial agglomerations of economic, political and social agents focusing on a specific set of the economic activities, mutually connected, albeit incipient and with general innovative orientation.

LPS include not only manufacturing structures, but also a wide range of social, scientific research, financial institutions, infrastructure, etc. (see Figure 2) that create a complex essential for the socio-economic development of the region. 


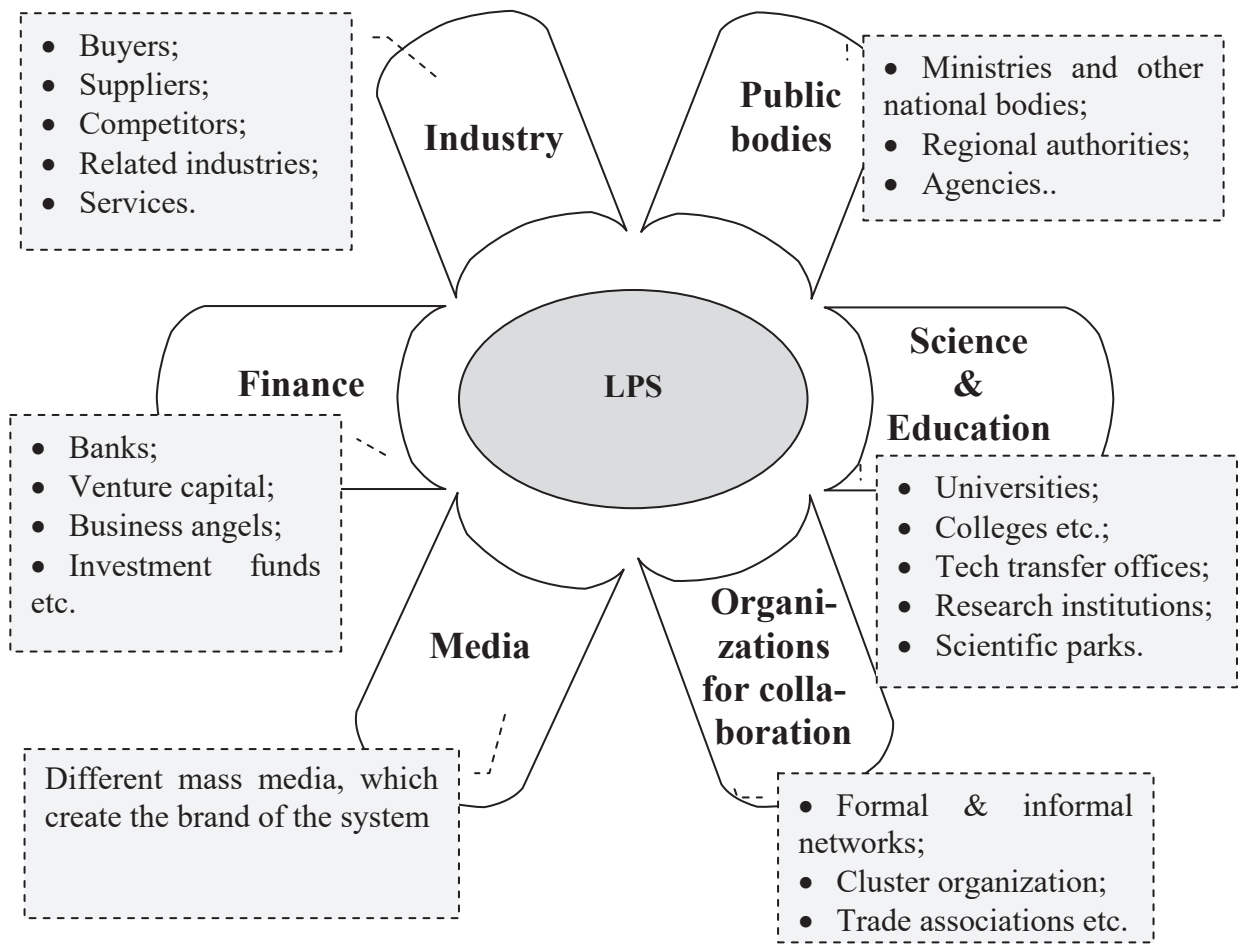

Figure 2. Environment of LPS

Source: author's modification of (Sölvell 2009).

In addition to the participants indicated in figure 2, various supporting institutions are often created with the main task to promote the emerging new agglomerative formations (including typical local production systems) and the establishment of cooperation within the existing ones (the so-called facilitators).

\section{INDUSTRIAL DISTRICTS AND AGGLOMERATIONS IN UKRAINE}

Some Ukrainian and Russian economists equate "cluster" with "spatial manufacturing complex", the theoretical basis of which was developed by M. Koloskovskyi in the 1930s (Golikov 2009: 28). According to his definition, a spatial manufacturing complex "is an economically integrated, interconnected and interdependent association of various sectors of the economy that emerged and developed in a particular area." So it is rather a Marshallian type of agglomeration's definition. 
Indeed, economic policy of the Soviet Union in the mid-1960s, which included planning of the economic development based on the spatial principle, has got many points in common with modern cluster approach. For example, the Office of Tractor and Agricultural Machinery of Kharkiv public farm complex, in addition to traditional vertically integrated production, includes also technical schools, colleges, and specialized design institutes. Similar associations were observed in chemical, textile, paper and wood processing, construction materials industries, etc. However, it is not correct to equate a cluster and a SMC, because the second one is a much broader term, which covers both clusters and industrial districts, which are common regional concentrations of certain industry without any clear innovation focus.

Currently, at the territory of Ukraine, four multisectoral industrial districts have been formed: Donetsk (coal, electric power, metallurgy, machine-building and chemical industries), Dnieper (electricity, chemicals, machinery and metallurgy), Carpathian (oil and gas, forestry, engineering and chemical industry) and Bug (coal, chemical and electric power industries).

Many industrial agglomerations are located within industrial districts. Donetsk-Makeyevka, Gorlivka-Yenakiyevo, Luhansk industrial agglomeration belong, for example, to the Donetsk Industrial District, Dnipropetrovsk-Dniprodzerzhynsk, Zaporizhia, Kryvyi Rig - to the Dnipro region, Lviv agglomeration - to the Carpathian, Novovolynsk and Chervonohrad - to Bug. Outside of e industrial districts there are Kyiv, Kharkiv, and Odessa industrial agglomeration (Table 1). All these elements of the spatial organization of industry are connected with various ties typical for industrial complex in Ukraine (Hiletskyi 2003: 160).

Next step of the research is to identify the most favorable industries that could develop into agglomerations in Ukraine. There are a number of indices used for analysing different aspects of industrial concentration: Locational Gini Index (Krugman 1991), EG Index (Ellison, Glaeser 1997), Clustering Index (Hallet 2000) etc. In this paper we used the Coefficient of Regional and Industrial Concentration (sometimes called the Localization Coefficient), which represents both territorial and sectoral dimensions of agglomeration (Ruiz-Valenzuela, Moreno-Serrano, Vayá-Valcarce 2007):

Table 1

Industrial districts \& industrial agglomerations in Ukraine

\begin{tabular}{|c|c|c|c|l|}
\hline $\begin{array}{c}\text { Industrial } \\
\text { districts }\end{array}$ & $\begin{array}{c}\text { Industrial agglom- } \\
\text { erations }\end{array}$ & $\begin{array}{c}\text { Population } \\
\text { (thousands) }\end{array}$ & $\begin{array}{c}\text { Area } \\
\mathbf{( k m}^{2} \mathbf{)}\end{array}$ & \multicolumn{1}{|c|}{ Factors of growth } \\
\hline 1 & 2 & 3 & 4 & 5 \\
\hline \multirow{3}{*}{ Donetsk } & Donetsk-Makiivka & 2009.7 & 8093 & mining, machine building, transit \\
\cline { 2 - 5 } & Gorlivka-Yenakievo & 782.7 & 2708 & Coal \\
\cline { 2 - 5 } & Luhansk & 501.2 & 4352 & $\begin{array}{l}\text { machine building, fuel, textile, } \\
\text { transport }\end{array}$ \\
\hline
\end{tabular}


Table 1 (cont.)

\begin{tabular}{|c|c|c|c|l|}
\hline 1 & 2 & 3 & 4 & \multicolumn{1}{|c|}{5} \\
\hline \multirow{2}{*}{ Dnieper } & $\begin{array}{c}\text { Dnipropetrovsk-Dni- } \\
\text { prodzerzhynsk }\end{array}$ & 1859.5 & 12887 & $\begin{array}{l}\text { mining, machine building, transit } \\
\text { crossroad, Dnieper river }\end{array}$ \\
\cline { 2 - 5 } & Zaporizhia & 1100.9 & 8200 & $\begin{array}{l}\text { metallurgy, machine building, tran- } \\
\text { sit crossroad, Dnieper river }\end{array}$ \\
\cline { 2 - 5 } & Kryvyi Rih & 1010 & & $\begin{array}{l}\text { close to the centers of mining, met- } \\
\text { allurgy, sea }\end{array}$ \\
\hline $\begin{array}{c}\text { Carpath- } \\
\text { ian }\end{array}$ & Lviv & 1498.0 & 9096 & $\begin{array}{l}\text { center of the western Ukraine close } \\
\text { to the EU }\end{array}$ \\
\hline \multirow{2}{*}{ Bug } & Novovolynsk & 243.5 & 3551 & $\begin{array}{l}\text { food industry, tourism, close to the } \\
\text { border }\end{array}$ \\
\cline { 2 - 6 } & Chervonohrad & 183.1 & 1590 & coal, transport \\
\hline- & Kyiv & 3648.9 & 13534 & capital of Ukraine, services \\
\hline- & Kharkiv & 2157.5 & 11847 & science, transport, machine building \\
\hline - & Odesa & 1546.6 & 9780 & $\begin{array}{l}\text { sea, international trade, recreation, } \\
\text { culture }\end{array}$ \\
\hline
\end{tabular}

Source: compiled by author from different official statistic surveys and (Giletskyi 2003: 160).

$$
\begin{aligned}
& L_{i j}=\frac{E_{j} / E_{i}}{E_{j} / E} \\
& i=1,2, \ldots, N \\
& j=1,2, \ldots, R
\end{aligned}
$$

where:

$E_{\mathrm{ij}}$ - employment in industry $j$ and country $i$,

$E_{\mathrm{i}}$ - total employment in region $i$,

$E_{\mathrm{j}}-$ total employment in industry $j$,

$E$ - total employment in Ukraine.

If $L_{\mathrm{ij}}>1\left(L_{\mathrm{ij}}<1\right)$, region specializes in industry $j$ to a bigger (smaller) extent in comparison to general national indicator. The base of the research comprised 25 regions ("oblast") of Ukraine in 2013.

The results of the research are presented in Table 2, where the values of the coefficient exceeding 1 are highlighted with colour. The highest values are observed for light industry in Zakarpattia, Lviv and Zhytomyr regions; woodworking in Volyn; food industry in Kyiv, Zhytomyr and Lviv regions. These industries should be priority ones for regional authorities when developing regional industrial strategies. 
Matrix of industrial and regional concentration in Ukraine, $2013^{2}$

\begin{tabular}{|c|c|c|c|c|c|c|c|c|c|c|}
\hline & 亩 & 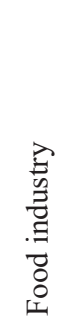 & 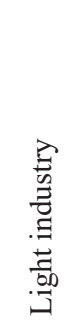 & 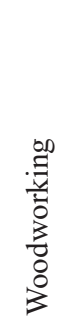 & 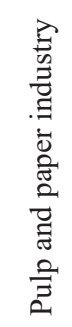 & 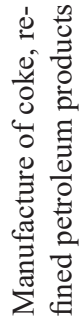 & 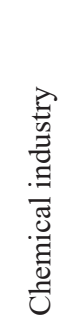 & 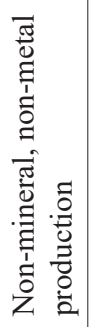 & 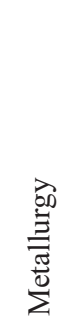 & 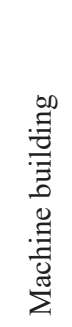 \\
\hline AR Crimea $^{2}$ & 0,09 & 1,54 & 1,57 & 0,17 & 0,57 & 0,00 & 0,17 & 0,62 & 0,32 & 1,92 \\
\hline Vinnytsia & 0,21 & 2,51 & 1,81 & 0,56 & 0,80 & 0,00 & 0,60 & 1,25 & 0,25 & 0,92 \\
\hline Volyn & 0,59 & 1,78 & 1,53 & 3,54 & 1,03 & 0,00 & 0,41 & 1,09 & 0,27 & 1,19 \\
\hline Dnipropetrovsk & 1,57 & 0,52 & 0,25 & 1,07 & 0,59 & 0,62 & 1,12 & 0,50 & 2,02 & 0,75 \\
\hline Donetsk & 2,01 & 0,51 & 0,22 & 0,07 & 0,46 & 2,69 & 0,37 & 1,07 & 2,09 & 0,10 \\
\hline Zhytomyr & 0,67 & 1,56 & 2,62 & 1,79 & 2,71 & 0,00 & 0,67 & 2,85 & 0,28 & 0,72 \\
\hline Zakarpattia & 0,25 & 0,82 & 5,72 & 10,7 & 0,77 & 0,01 & 0,50 & 0,72 & 0,08 & 1,28 \\
\hline Zaporizhzhia & 0,20 & 0,56 & 0,57 & 0,26 & 0,34 & 0,93 & 0,39 & 0,81 & 1,78 & 1,75 \\
\hline Ivano-Frankivsk & 0,80 & 0,74 & 1,61 & 5,55 & 1,07 & 1,34 & 2,31 & 2,39 & 0,19 & 0,39 \\
\hline Kyiv & 0,04 & 1,58 & 1,39 & 0,94 & 3,20 & 2,24 & 2,43 & 1,73 & 0,42 & 0,64 \\
\hline Kirovohrad & 0,88 & 1,51 & 0,73 & 0,42 & 0,94 & 0,00 & 0,69 & 1,42 & 0,37 & 1,21 \\
\hline Luhansk & 2,31 & 0,47 & 0,62 & 0,06 & 0,45 & 1,31 & 1,92 & 0,45 & 0,83 & 0,68 \\
\hline Lviv & 0,75 & 0,92 & 2,89 & 1,67 & 3,14 & 0,89 & 0,84 & 1,74 & 0,14 & 1,20 \\
\hline Mykolaiv & 0,10 & 1,14 & 1,38 & 0,16 & 0,51 & 0,00 & 0,09 & 0,60 & 0,30 & 2,09 \\
\hline Odesa & 0,02 & 2,00 & 0,24 & 0,30 & 1,64 & 0,00 & 1,69 & 1,07 & 0,36 & 1,19 \\
\hline Poltava & 0,84 & 1,50 & 0,82 & 0,06 & 0,05 & 2,31 & 0,30 & 0,87 & 0,46 & 1,53 \\
\hline Rivne & 0,30 & 1,10 & 1,12 & 6,94 & 0,98 & 0,00 & 2,42 & 2,48 & 0,37 & 0,30 \\
\hline Sumy & 0,40 & 1,07 & 1,07 & 0,73 & 0,47 & 0,05 & 2,30 & 0,77 & 0,19 & 2,05 \\
\hline Ternopil & 0,26 & 2,34 & 2,45 & 1,35 & 1,51 & 0,00 & 0,51 & 1,93 & 0,14 & 0,68 \\
\hline Kharkiv & 0,16 & 1,03 & 0,78 & 0,49 & 2,16 & 0,32 & 0,95 & 1,12 & 0,29 & 2,13 \\
\hline Kherson & 0,13 & 1,38 & 2,10 & 0,16 & 1,20 & 0,00 & 0,61 & 0,71 & 0,22 & 1,91 \\
\hline Khmelnytskyi & 0,15 & 1,70 & 0,70 & 0,90 & 1,02 & 0,00 & 0,08 & 0,33 & 0,29 & 1,48 \\
\hline Cherkasy & 0,22 & 2,09 & 1,37 & 1,46 & 1,04 & 0,00 & 2,16 & 0,55 & 0,22 & 1,10 \\
\hline Chernivtsi & 0,10 & 2,48 & 1,29 & 2,24 & 1,55 & 0,00 & 0,54 & 2,13 & 0,16 & 0,51 \\
\hline Chernihiv & 0,36 & 1,83 & 2,85 & 1,17 & 1,97 & 0,00 & 1,78 & 0,45 & 0,23 & 0,98 \\
\hline
\end{tabular}

Source: author's calculations on the data of National Statistics Service of Ukraine.

\footnotetext{
${ }^{2}$ The paper was submitted before Crimea's occupation by Russia Federation.
} 
The Diversification Index $D I^{j}$ was also calculated; its high value shows relative homogeneity of production activities distribution in various sectors of the region.

$$
D I^{j}=\frac{1 / \Sigma_{j j}\left(\frac{E^{j}}{\sum_{j} E^{j}}\right)^{2}}{1 / \sum_{i}\left(\frac{\Sigma_{j} E^{j}}{\Sigma_{i} \Sigma_{j} E^{j}}\right)^{2}}
$$

The results of calculations are represented in Table 3. High value of the index indicates that a region has good conditions for the development of other type of agglomeration - creative region. The most diversified and less dependent from limited types of industries are Rivne $\left(D I^{j}=0,089\right)$, Ivano-Frankivsk $\left(D I^{j}=0,065\right)$ and Khmelnytsk regions $\left(D I^{j}=0,054\right)$.

Table 3

Diversification Index $D I^{j}$ for the regions of Ukraine, 2013

\begin{tabular}{|l|l|l|l|}
\hline \multicolumn{1}{|c|}{ Region } & $D I^{\mathrm{j}}$ & \multicolumn{1}{c|}{$D^{\mathrm{j}}$} \\
\hline AR Crimea & 0.021 & Mykolaiv & Mykolaiv \\
\hline Vinnytsia & 0.018 & Odesa & Odesa \\
\hline Volyn & 0.017 & Poltava & Poltava \\
\hline Dnipropetrovsk & 0.005 & Rivne & Rivne \\
\hline Donetsk & 0.007 & Sumy & Sumy \\
\hline Zhytomyr & 0.014 & Ternopil & Ternopil \\
\hline Zakarpattia & 0.010 & Kharkiv & Kharkiv \\
\hline Zaporizhzhia & 0.015 & Kherson & Kherson \\
\hline Ivano-Frankivsk & 0.065 & Khmelnytskyi & Khmelnytskyi \\
\hline Kyiv & 0.034 & Cherkasy & Cherkasy \\
\hline Kirovohrad & 0.021 & Chernivtsi & Chernivtsi \\
\hline Luhansk & 0.005 & Chernihiv & Chernihiv \\
\hline Lviv & 0.017 & & \\
\hline
\end{tabular}

Source: author's calculations on the data of National Statistics Service of Ukraine. 


\section{SPECIFIC LEGAL REGIMES AS PRECONDITION FOR LPS DEVELOPMENT IN UKRAINE}

Taking into account the peculiarities of individual territories, the government of Ukraine developed a number of specific legal regimes of the economic activity. As at today there are four regimes:

- special (free) economic zones,

- priority development areas,

- technology parks,

- science parks.

These regimes should be considered a good basis for the new LPS. Besides, a lot of currently existing LPS are situated within the territories covered with specific regimes of public support for economic activity.

Special (free) economic zones (SEZ) are parts of the national territory, where special legal regime of the economic activity is established with the aim to strengthen external relations by actively attracting foreign capital. On the other hand, priority development areas (PDA) are defined as territories within the city area with adverse socio-economic conditions, where a special regime for investments is introduced to create new jobs. In January 1, 2013 under the current law, 11 special (free) economic zones and 72 priority development areas were established in Ukraine.

Special economic zones operate in nine regions with a special investment regime Crimea ( 7 districts), Donetsk region (22 cities and 5 districts), Volyn ( 3 cities and 9 districts), Transcarpathia, Luhansk ( 6 cities, 3 districts) Chernihiv region (7 districts), Shostka and Kharkiv. The most famous among them are "Donetsk", "Slavutych" in Kyiv, "Truskavets Resort" in Lviv, "Mykolaiiv". There are also special economic zones with foreign aspirations: "Azov", "Transcarpathia", "Interport Kovel", "Renee", "Porto Franco" of Odesa Sea Commercial Port, "Port Crimea" and South Crimean experimental zone "Sywash" (Ivanenko 2009).

A standard set of benefits includes also a partial exemption of the income tax, customs duty and VAT, in some cases preferential land tax or government guarantees, and investment protection. In addition, the government establishes a list of imported raw materials, equipment which can be imported for the investment projects on favorable terms. Companies periodically report the use of imports to tax and customs services and to the administration of special areas. The government determines the list of priority activities, giving certain basic industries a special status. 


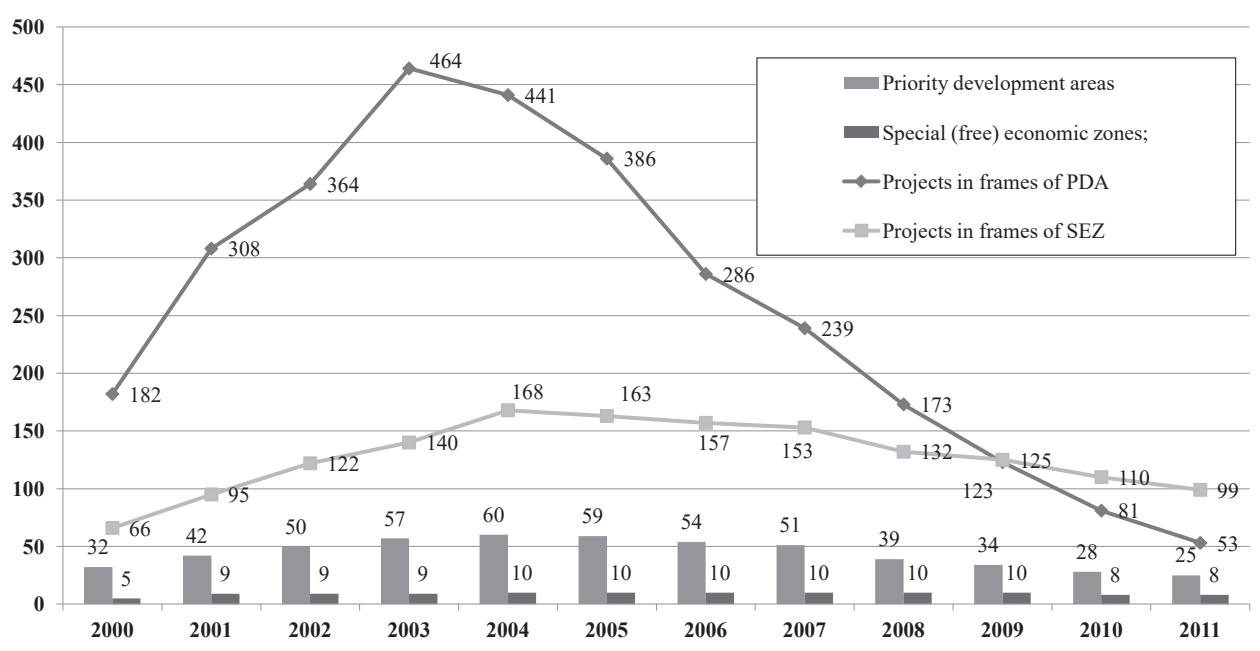

Figure 3. Special economic zones and priority development areas in Ukraine Source: (Government Portal 2013).

By 2005, most Ukrainian PDAs evolved rapidly together with the increase in major economic indicators (Figure 3). Most significant results were achieved by entities of PDA in the Donetsk region. But PDA as an economic instrument was used without a strategic plan and not always purposefully. Under the influence of a number of negative factors, currently the economic effect of PDA is not sufficient.

Unfortunately, the SEZ and PDA practice has shown their ineffectiveness in Ukraine. Using them as a "legitimate" instrument to minimize import taxes and duties, the companies that implement investment projects on preterential conditions spoil competitive environment in the market. The "Ukrainian economic miracle" consisted in the fact that SEZs, instead of being catalysts of economic development (as for example it is the case in Poland) often became "black holes" in the state budget and a good source for dishonest businessmen and their representatives in the authorities (Ivanenko 2009).

\section{CURRENT LPS IN UKRAINE}

But in spite of not very favorable institutional conditions, absence of legal framework and public support, some LPS still managed to develop in Ukraine (at national level they are called clusters). First attempts to create clusters date back to 1998. Nowadays, there are more than two dozen clusters in Ukraine. Most important clusters are presented in Table 4. 
Clusters in Ukraine

\begin{tabular}{|c|c|}
\hline Region & Clusters \\
\hline Khmelnytskyi & $\begin{array}{l}\text { - Khmelnytskyi construction cluster; } \\
\text { - Khmelnytskyi sewing cluster; } \\
\text { - Khmelnytskyi touristic cluster; } \\
\text { - Kamianets-Podilsk touristic cluster; } \\
\text { - Cluster of the eco-agrotourism in Grytsive, Shepetivka district "Amulet"; } \\
\text { - Fruit cluster "Podilsk apple". }\end{array}$ \\
\hline Crimea & $\begin{array}{l}\text { - Mega-cluster "Sevastopol"; } \\
\text { - Ecological Cluster "Vtorma-cluster"; } \\
\text { - Innovation Cluster "Intellect-resource"; } \\
\text { - Innovation Cluster "EcoEnergy"; } \\
\text { - Cluster "Eurostandard UA". }\end{array}$ \\
\hline $\begin{array}{c}\text { Iva- } \\
\text { no-Frankivsk }\end{array}$ & $\begin{array}{l}\text { - Cluster "Suziria" (manufacturing of souvenirs); } \\
\text { - Cluster "Manufacturing of ethnic products Prykarpattia" (manufacturing } \\
\text { products from sheep's wool). }\end{array}$ \\
\hline Rivne & - Cluster of wood Rokytne district; \\
\hline Kherson & - Transport-logistics cluster "Southern gateway of Ukraine"; \\
\hline Poltava & - Cluster of ecological food for children based on organic farming; \\
\hline Kharkiv & - Cluster of pigs breeding and meat products; \\
\hline Odesa & - Cluster of organic farming and green tourism in the Danube region. \\
\hline
\end{tabular}

Source: (Lishchynskyy 2014: 190-202).

As we can see, the area of LPS location is rather limited - the lion's share of all clusters function in 3 regions (Khmelnytskyi, Ivano-Frankivsk, and the Crimea), which necessitates active development of regional economic policy in this area. Most Ukrainian cluster initiatives are observed in industry, tourism and leisure, transport and logistics, agriculture.

Despite the fact that 15 years passed since the emerging of the first cluster in Ukraine, their status as institutional units of national economy is still uncertain. This causes some difficulties in obtaining information about the total quantity and their activities, internal structure and, most importantly, their impact on economic development of certain regions and national economy as a whole. Some pieces of information can be found in scientific publications, on the web-sites of regional authorities, in special reviews and reports by domestic and foreign authors, etc., but it often differs substantially one from another and needs further systematization and generalization.

The process of clustering in the Ukrainian economy, which began spontaneously in the last 2-3 years has been closely followed by the public opinion. The need to introduce a cluster approach as a priority direction of innovation is recently 
noted in almost all regulations, programs relating to the issues of investment and innovation.

The main and the most recent tasks of the Government in the related field should be as follows:

- administrative and territorial reform in Ukraine, which should be based on the principles of decentralization, deconcentration of authority, subsidiarity, financial federalization,

- not only development and adoption of regional development programs for the next decade (which has been done for most regions of Ukraine), but also regular monitoring of their performance,

- development of investment and innovation development programs for the whole regions and for separate locations (including grants of international organizations, loans from the European Development Bank, other than budgetary funding sources),

- reducing negative trends in employment related to excessive emigration (including the "brain-drain"), high unemployment, lack of new jobs,

- fostering education (combating corruption in education, review training requirements for government contracts, special scholarships for the most talented students),

- creation of business incubators, technology parks and other techno- and innovative structures.

So, benchmarking of world practices and the development of regional growth strategy on the basis of LPS can guarantee not only the survival of traditional heavy industrial centers in Ukraine, but also ensure favorable conditions for emerging small and medium enterprises, which can be competitive in national and world markets.

\section{CONCLUSIONS}

In summary, it should be noted that various agglomeration and innovation structures in Ukraine are at the early stages of their formation and their effectiveness is far from optimal. Particularly, one of the biggest challenges is the improvement of the regulatory and legal framework for Ukrainian LPS. It should create favorable conditions for the cooperation of businesses, government, science, education, and civil society groups within the clusters. The term "cluster" is rather common in a variety of government programs, but still there is no even legal definition of it. The Laws of Ukraine "On the innovation activity", "On scientific and technical activity", "On priority directions of the innovative activity in Ukraine", "On special investment and innovation of technology parks", should be adapted in accordance with the practice of the European Union. 
First steps towards the development of cluster strategies have already been taken by the central Government. In October 19, 2010 the Ministry of Economy of Ukraine issued a decree "On the establishment of the Working Group on the cluster development in Ukraine". However, the initiatives proposed by the created working group, unfortunately, have not found a real support at the national level yet.

\section{REFERENCES}

Artemenko L. (2004), Potentsial rozvytku transkordonnykh rehioniv na osnovi innovatsiinykh klasteriv, http://old.niss.gov.ua/Evrointeg/FORUM/ukr/program.htm.

Bidziura I. (2004), Vilni ekonomichni zony yak instrument aktualizatsii regionalnoi polityky Ukrainy, "Trybuna", vol. 7, p. 30-31.

European Cluster Organisation Directory, http://www.europe-innova.eu/c/document_library/get file? folderId=148901\&name=DLFE-9316.pdf.

Golikov A., Kazakova N., Prav Y. (2009), Regionalnaia politika i ekonomicheskoe razvitie: evropeiskiy kontekst, Ekograf, Kharkov, p. 28-29.

Government portal (2013), http://www.kmu.gov.ua/control/publish/article?art_id=3249330.

Hallet M. (2000), Regional Specialization and Concentration in the EU, Economic Papers of the European Commission, Directorate-General for Economic and Financial Affairs, no. 141.

Hiletskyi Y. (2003), Heohrafiia Ukrainy, VNTL-Klasyka, Lviv, p. 160.

Ivanenko O. (2009), Spetsialni ekonomichni zony: svitovyi dosvid i dosvid Ukrainy, "Visnyk tsentru", vol. 72.

Krugman P. (1980), Scale Economies, Product Differentiation and the Pattern of Trade, "American Economic Review", vol. 70(5), p. 950-959.

Krugman P. (1991a), Geography and Trade, The MIT Press, Cambridge, Massachusetts.

Lindqvist G., Protsiv S., Sölvell Ö. (2008), Regions, innovation and economic prosperity: evidence from Europe, Center for Strategy and Competitiveness-CSC Working Paper, Stockholm.

Lishchynskyy I. (2014), Agglomerationsformen der Internationalen Wirtschafts- und Raumintegration, "The world economy: global and country-specific aspects", Forschungsinstitut der Internationalen Wissenschaftlichen Vereinigung Weltwirtschaft und Weltpolitik e.V., Berlin, p. 190-202.

Lyzun M. (2013), Besonderheiten der Entwicklung des Franchising: Europäische Tendenzen und ukrainischen Realien, Platzbestimung Ostöuropas in der Sozio-Ökonomischen Globalisierung, Berlin, p. 316-331.

Mochernyi S. (2002), Ekonomichna entsyklopediia: u trokh tomakh, vol. 1, K.: Akademiia.

Ruiz-Valenzuela J., Moreno-Serrano R., Vayá-Valcarce E. (2007), Has concentration evolved similarly in manufacturing and services? A sensitivity analysis, Documents de Treball 2007/8, p. 44.

Sölvell Ö. (2009), Clusters. Balancing Evolutionary and Constructive Forces, Danagårds Graiska, Ödeshög, p. 140.

Sölvell Ö., Lindqvist G., Ketels C. (2003), The Cluster Initiative Greenbook, Ivory Tower, Stockholm.

Varnaliy Z. (2005), Rehiony Ukrainy: problemy ta priorytety sotsialno-ekonomichnoho rozvytku, K.: Znannia Ukrainy, p. 498.

World Development Report 2009: Reshaping Economic Geography, web.worldbank.org. 